\title{
APPLICATION OF MAGIC BALL-BASED GROUP INVESTIGATION MODELS TO IMPROVE COLLABORATIVE SKILLS AND STUDENT LEARNING MATHEMATICS RESULTS
}

\author{
Rusmidah \\ SDN 008 Talang Perigi, Rakit Kulim, Indonesia \\ st.984411@gmail.com
}

\section{ABSTRACT}

This research is motivated by teacher-centered learning that caused the lack of student activity in solving problems and finding answers together. This research aims to improve mathematical collaborative skills and student learning outcomes through the application of a magic ball-assisted group investigation learning model. The subject of the research was a classroom action research study on third grade students at SDN 008 Talang Perigi. The instrument used was the observation sheet and learning outcomes test. The results showed in the first cycle of collaborative mathematical skills students obtained an average of 55.77\% with a high category and in the second cycle increased to $73.44 \%$ with a very high category. Student learning outcomes in the first cycle had an average of 67.83 with a percentage of classical completeness of $53 \%$, increasing in the second cycle to 75.67 with a percentage of classical completeness of $83 \%$. Based on the findings, it can be concluded that the application of the learning model of investigation ball assisted by magic ball can improve the collaborative skills of mathematics and learning outcomes of third grade students of SDN 008 Talang Perigi.

Keywords: group investigation, magic ball, collaborative skill, learning outcomes

\section{PENERAPAN MODEL INVESTIGASI KELOMPOK BERBASIS MAGIC BALL UNTUK MENINGKATKAN KETERAMPILAN KERJA SAMA DAN HASIL MATEMATIKA SISWA}

\begin{abstract}
ABSTRAK
Penelitian ini dilatarbelakangi oleh pembelajaran yang berpusat pada guru sehingga kurangnya aktivitas siswa dalam memecahkan masalah dan menemukan jawaban secara bersama. Penelitian ini bertujuan untuk meningkatkan collaborative skill matematika dan hasil belajar siswa melalui penerapan model pembelajaran group investigation berbantuan magic ball. Penelitian ini merupakan penelitian tindakan kelas terhadap siswa kelas III SDN 008 Talang Perigi. Instrumen yang digunakan adalah lembar observasi dan tes hasil belajar. Hasil penelitian menunjukkan pada siklus I collaborative skill matematika siswa memperoleh rata-rata sebesar 55.77\% dengan kategori tinggi dan pada siklus II meningkat menjadi $73.44 \%$ dengan kategori sangat tinggi. Hasil belajar siswa pada siklus I memiliki rata-rata sebesar 67.83 dengan persentase ketuntasan klasikal sebesar 53\% mengalami peningkatan pada siklus II menjadi 75.67 dengan persentase ketuntasan klasikal sebesar 83\%. Berdasarkan hasil penelitian dapat disimpulkan bahwa penerapan model pembelajaran group investigation berbantuan magic ball dapat meningkatkan collaborative skill matematika dan hasil belajar siswa kelas III SDN 008 Talang Perigi.
\end{abstract}

Kata Kunci: group investigation, magic ball, collaborative skill, hasil belajar

\begin{tabular}{|c|c|c|}
\hline Submitted & Accepted & Published \\
\hline 02 Maret 2020 & 17 Maret 2020 & Maret 2020 \\
\hline
\end{tabular}

\begin{tabular}{|l|l|r|r|}
\hline Citation & $:$ & $\begin{array}{r}\text { Rusmidah. (2020). Application Of Magic Ball-Based Group Investigation Models To Improve Collaborative Skills And } \\
\text { Student Learning Mathematics Results. Jurnal PAJAR (Pendidikan dan Pengajaran), 4(2), 390-399. DOI : } \\
\text { http://dx.doi.org/10.33578/pjr.v4i2.7976. }\end{array}$ \\
\hline
\end{tabular}

\section{PENDAHULUAN}

Proses pendidikan di sekolah harus mengupayakan peningkatan kemampuan dan keterampilan siswa secara kognitif, afektif, dan psikomotorik yang tercermin dari kecakapan siswa dalam bidang akademik dan keterampilan. Salah satu cabang ilmu yang harus dikuasai oleh siswa adalah matematika yang dapat menggali kemampuan berpikir dan keterampilan baik individu maupun kelompok. Peran sekolah melalui guru adalah memfasilitasi kegiatan belajar siswa dan mengarahkan agar siswa belajar secara aktif 
sehingga tercipta pembelajaran yang berpusat pada siswa (student center).

Hal utama yang perlu diperhatikan dan dipahami guru adalah setiap siswa memiliki kemampuan dan cara yang berbeda dalam belajar, namun guru dapat melihat karakteristik siswa secara menyeluruh yakni siswa SD menyukai pembelajaran yang bersifat fisik terlebih didesain dengan permainan. Siswa lebih senang melakukan kegiatan untuk menemukan sesuatu dibandingkan disajikan soal untuk dijawab ataupun diberikan informasi secara menyeluruh (ceramah). Siswa SD sangat suka bermain bersama, jadi guru harus mampu mengolah pembelajaran yang menciptakan suasana kebersamaan.

Keterampilan siswa dalam berkolaborasi pada mata pelajaran matematika atau dikenal dengan collaborative skills sudah menjadi keharusan bagi siswa dalam menjalani abad 21 . Melalui kerjasama siswa dapat mengembangkan kepercayaan dirinya, pengalaman belajar bertambah, dan membantu interaksi siswa dengan guru dan siswa lainnya (Rosita, 2013). Keterampilan berkolaborasi dapat menumbuhkan tanggung jawab dan motivasi siswa untuk melakukan yang terbaik karena melalui kerjasama siswa dapat saling berbagi tugas dan peran dalam melakukan kegiatan secara bersama.

Berdasarkan hasil observasi di lapangan dijumpai bahwa masih banyak pembelajaran yang berpusat pada guru (teacher center) sehingga kemampuan dan keterampilan siswa tidak mendapatkan fasilitas yang selayaknya didapatkan siswa abad 21. Ditemukan bahwa guru masih

\section{KAJIAN TEORETIS \\ Model Pembelajaran Group Investigation}

Model pembelajaran merupakan kerangka konseptual berisi sintaks pembelajaran yang sistematis untuk melaksanakan, mengorganisasikan pembelajaran sebagai upaya mencapai tujuan pembelajaran (Avisca, dkk. 2018). Model pembelajaran group investigation adalah model pembelajaran kooperatif sebagai media untuk mendorong dan membimbing keterlibatan siswa dalam belajar, melalui pelaksanaan investigasi yang dipilih siswa akan dominan dalam menyampaikan materi, dan pada pertengahan atau akhir peremuan guru memberikan latihan soal. Sehingga kemampuan siswa masih rendah, siswa menyatakan bahwa mereka lupa rumus dan bahkan kurang memahami penjelasan guru. Seyogyanya peran guru harus mampu menanamkan konsep dasar, siswa memahami konsep yang ditanamkan, kemudian guru melatih dan membimbing siswa dalam menerapkan konsep matematika yang dipahami ke dalam permasalahan yang erat kaitannya dengan siswa (Heruman dalam Kristianti, 2019). Selain itu guru tidak pernah melakukan pembelajaran secara berkelompok baik untuk berdiskusi maupun melakukan investigasi terhadap suatu permasalahan.

Mengacu pada permasalahan tersebut, peneliti tertarik untuk melakukan penelitian sebagai upaya meningkatkan collaborative skill matematika siswa melalui suatu model pembelajaran yang memfasilitasi siswa secara berkelompok dalam melakukan investigasi, model ini dikenal dengan group investigation. Melalui model ini diharapkan dalam memiliki hasil yang positif terhadap keterampilan kolaborasi siswa karena menurut Avisca, dkk (2018) bahwa pembelajaran dengan model group investigation dapat meningkatkan keterampilan berpikir kritis dan kolaborasi siswa pada mata pelajaran matematika. Model group investigation dengan bantuan magic ball memfasilitasi siswa untuk bekerja sama dalam memecahkan permasalahan yang disajikan.

lebih aktif dalam melakukan kegiatan berupa komunikasi dan kerjasama dalam merencanakan dan melaksanakan investigasi (Suprijono, 2009). Menurut Sadikin (2016) bahwa group investigation merupakan kelompok kecil untuk menuntun dan mendorong siswa dalam keterlibatan belajar.

Pada model group investigation, siswa tidak harus menghafal fakta atau konsep, tetapi mendorong siswa mengkonstruksi di benak sendiri (Agustina, 2011). Hal ini menandakan bahwa pengetahuan siswa dapat terbentuk atau terbangun 
di dalam pikiran siswa ketika ia berupaya untuk mengorganisasikan pengalaman barunya berdasarkan kerangka kognitif yang sudah ada dalam pikirannya.

Menurut Sharan dalam Lestari (2017) terdapat 6 tahapan strategi belajar kooperatif group investigation yakni: 1) menentukan topik diskusi,
2) merencanakan investigasi, 3) melakukan investigasi, 4) merancang presentasi, 5) mempresentasikan temuan, 6) melakukan evaluasi bersama guru. Lebih lanjut aktivitas siswa dalam pembelajaran group investigation dapat dilihat lebih jelas pada tabel berikut:

Tabel. 1. Langkah-langkah Model Pembelajaran Group Investigation

\begin{tabular}{|c|c|c|}
\hline No. & Langkah-langkah & Aktivitas Siswa \\
\hline 1. & Pengelompokan & $\begin{array}{l}\text { Guru membagi siswa menjadi kelompok dengan jumlah yang merata dan } \\
\text { heterogen }\end{array}$ \\
\hline 2. & Perencanaan & $\begin{array}{l}\text { Guru membimbing siswa dalam perencanaan untuk menentukan cara pemecahan } \\
\text { masalah }\end{array}$ \\
\hline 3. & Investigasi & $\begin{array}{l}\text { Memahami permasalahan dengan berbagai cara alternatif dan menentukan } \\
\text { jawaban }\end{array}$ \\
\hline 4. & Pengorganisasian & Mengelompokkan masalah berdasarkan cara pemecahannya \\
\hline 5 . & Presentasi & $\begin{array}{l}\text { Kelompok yang ditunjuk guru mempresentasikan hasil pemecahan masalah di } \\
\text { depan kelas dan kelompok lain memberikan tanggapan }\end{array}$ \\
\hline 6. & Evaluasi & $\begin{array}{l}\text { Guru mengevaluasi kegiatan siswa dengan pertanyaan dan pengambilan } \\
\text { kesimpulan bersama siswa }\end{array}$ \\
\hline
\end{tabular}

Berdasarkan langkah-langkah yang disajikan tersebut terlihat bahwa model pembelajaran ini sangat kompleks karena memadukan segala keterampilan siswa berupa keterampilan bersosialisasi, berkomunikasi, inquiri, pemecahan masalah, dan penyampaian atau tanggapan. Hal ini mempertajam gagasan siswa sehingga guru dapat mengetahui kemungkinan keliru atau tepatnya gagasan siswa yang dapat diperbaiki dengan yang lebih tepat (Isjoni, 2009).

Dalam penerapan model pembelajaran group investigation ini menggunakan media pembelajaran berupa magic ball. Magic ball merupakan media pembelajaran yang menggunakan bola warna warni, kertas soal, dan jawaban. Siswa diminta melakukan investigasi dengan mencari bola soal dan bola jawaban yang telah diletakkan di tempat-tempat tertentu di sekitar lingkungan sekolah, pencarian ini harus menyesuaikan antara soal dan jawaban yang tepat. Menurut Dienes dalam Halimah (2019) pembelajaran yang dikemas dalam sebuah permainan akan merangsang rasa ingin tahu dan semangat siswa dalam belajar.

Collaborative Skill
Dewasa ini siswa tidak hanya dituntut untuk bisa membaca, menulis, dan berhitung melainkan harus memiliki keterampilan yang lebih kompleks. Salah satu keterampilan yang harus dimiliki siswa abad 21 adalah collaborative skill atau keterampilan berkolaborasi / bekerja sama dalam melakukan kegiatan untuk mencapai tujuan. Keterampilan ini menurut Puspitasari (2017) merupakan 1 dari 4 keterampilan abad 21 yakni keterampilan berpikir kritis (critical thinking skills), keterampilan berpikir kreatif (creative thinking skills), keterampilan berkomunikasi (communication skills), dan keterampilan berkolaborasi (collaborative skills). Cooperative skill bukan hanya sekedar bekerja dalam kelompok, namun keterlibatan siswa dalam memberikan pendapat, keterampilan, untuk dapat mencapai tujuan pembelajaran yang maksimal (Avisca, dkk. 2018).

Indikator kolaborasi atau bekerja sama antara lain: 1) secara bersama-sama memiliki tanggung jawab dalam pemecahan masalah, 2) aktif berkontribusi dalam mengemukakan pendapat, 3) mengerahkan kemampuan secara maksimal, 4) membina hubungan baik dengan rekan, 5) menghadapi masalah bersama-sama, 6) 
percaya pada kemampuan anggota dalam kelompok, 7) memiliki prosedur kerja kelompok yang efektif, 8) mengutamakan keterampilan mendengar, 9) mengevaluasi proses kerja.

\section{Hasil Belajar}

Hasil belajar merupakan hasil dari usaha yang diperoleh dari pengalaman-pengalaman belajar untuk mencapai tujuan (Elhefni, 2011 dan

\section{METODE PENELITIAN}

Penelitian ini merupakan peneitian tindakan kelas (PTK), karena melihat latar belakang pembelajaran yang kurang melibatkan siswa untuk belajar secara aktif khususnya dalam keterampilan kolaborasi. Penelitian tindakan kelas dianggap tepat karena dilakukan secara bersiklus sampai tujuan yang ditetapkan tercapai. Siklus penelitian tindakan kelas dimulai dari tahap perencanaan (planning), pelaksanaan (action), pengamatan (observation), dan refleksi (reflection). pelaksanaan penelitian ini dilakukan bulan Januari 2020 dengan subjek siswa kelas III SDN 008 Talang Perigi yang berjumlah 30 siswa. Materi yang dilakukan penelitian adalah keliling dan luas persegi dan persegi panjang.

\section{Teknik Pengumpulan dan Pengolahan Data}

Data dikumpulkan dari hasil tes akhir dan pengamatan terhadap kegiatan siswa selama proses pembelajaran berlangsung menggunakan lembar observasi yang dipantau oleh observer. Hal ini digunakan untuk mengamati pembelajaran dan
Saleh, 2015). Jadi hasil belajar merupakan kemampuan yag diperoleh siswa dari proses pembelajaran yang telah dilakukan. Belajar dengan pengalaman langsung akan menghasilkan pemahaman yang lebih baik dan lebih bermakna bagi siswa. Tidak bisa dikatakan hasil belajar jika tidak didahului dengan proses atau pengalaman belajar.

menganalisis hambatan dan solusi yang tepat untuk dilakukan perbaikan. Data ini dikaji apakah pembelajaran yang dilakukan menerapkan model pembelajaran group investigation dengan bantuan magic ball sesuai perencanaan atau belum, jika masih terdapat kekurangan dan kekeliruan maka observer melakukan kritisi dan diskusi dengan peneliti agar mencapai tujuan pembelajaran yakni peningkatan collaborative skill matematika siswa. Data yang terkumpul diolah dengan cara mereduksi, kategorisasi, dan pengambilan kesimpulan. Tingkat keterampilan siswa diukur menggunakan rumus berikut:

Tingkat keterampilan $=\frac{\text { jumlah } \text { skor total subjek }}{\text { jumlah skor total maksimal }} \times 100 \%$

Setelah diperoleh tingkat keterampilan siswa, langkah selanjutnya mengkategorikannya ke dalam kategori keterampilan kolaborasi siswa pada tabel berikut:

Tabel 2. Rentang Skor dan Kategori Collaborative Skill Siswa

\begin{tabular}{cc}
\hline Rentang Skor $(\%)$ & Kategori Collaborative Skill \\
\hline$\geq 71.5$ & Sangat Tinggi \\
$55-70,5$ & Tinggi \\
$38.5-54$ & Sedang \\
$\leq 37.5$ & Rendah \\
\hline
\end{tabular}

Apabila persentase collaborative skill matematika siswa berada pada kategori sangat tinggi dengan minimal memperoleh rentang skor $71.5 \%$ maka penerapan model group investigation berbantuan magic ball dinyatakan berhasil. Artinya penerapan group investigation berbantuan magic ball dapat meningkatkan collaborative skill matematika siswa.

Sedangkan hasil belajar siswa dihitung menggunakan rumus berikut:

Ketuntasan klasikal $=\frac{\text { jumlah siswa yang mencapai } K K M}{\text { total siswa }} \times 100 \%$ 
Ketuntasan klasikal dinyatakan berhasil apabila sebanyak $80 \%$ memenuhi nilai KKM yakni 70.

\section{HASIL DAN PEMBAHASAN Tahap Perencanaan}

Sebelum penelitian diterapkan, guru terlebih dahulu melakukan kajian terhadap permasalahan yang dihadapi siswa guna menerapkan tindakan yang tepat, setelah diketahui maka guru menyiapkan dan menyusun rencana pembelajaran sesuai sintaks model pembelajaran yang dipilih yakni model pembelajaran group investigation, model ini dibantu menggunakan media magic ball dengan materi keliling dan luas persegi dan persegi panjang. Selain itu guru juga menyiapkan lembar observasi yang dijadikan alat untuk mencatat kegiatan pembelajaran yang dibantu oleh observer. Selain itu guru juga menyiapkan alat dan bahan pembelajaran serta lembar pertanyaan yang diinvestigasi oleh siswa dan mencari jawaban yang tepat yang terdapat pada magic ball. Dalam kegiatan pembelajaran siswa dibagi kedalam 6 kelompok yang setiap kelompok terdiri dari 5 siswa dengan kemampuan heterogen, maksudnya pembagian siswa secara merata yang meliputi siswa aktif dan biasa. Hasil pengamatan dijadikan bahan refleksi untuk tindakan pada siklus berikutnya.

\section{Tahap Pelaksanaan}

Mengacu pada tahapan model pembelajaran group investigation, pelaksanaan dimulai dengan membentuk kelompok yang telah dibagi oleh guru sebelumnya, kemudian guru membimbing dalam merencanakan kegiatan yang dilakukan selama pembelajaran, setelah rencana sudah matang dan dipahami dengan baik maka siswa melakukan investigasi terhadap persoalan yang disajikan guru dalam magic ball, masingmasing dalam organisasi kelompok harus bekerja sama memecahkan masalah yang disajikan, setelah kegiatan pengorganisasian dianggap tuntas maka masing-masing kelompok mempresentasikan hasil yang diperoleh kepada kelompok lainnya dengan dipantau dan dibimbing oleh guru, sehingga tahap akhir guru dapat memberikan masukan dan mengevaluasi proses pembelajaran yang dilaksanakan.

Selama proses pembelajaran berlangsung, guru mengkondisikan siswa agar melakukan kegiatan pembelajarn sesuai dengan perencanaan yang telah dibuat. Guru berupaya agar siswa aktif bekerjasama dalam kelompok dalam menemukan pemecahan masalah dengan melakukan investigasi dan berinteraksi satu sama lain, masing-masing harus memiliki peran seperti mengambil bola berisi soal, mencari jawaban, dan memilih bola yang berisi jawaban yang tepat. Kolaborasi ini dipercaya dapat meningkatkan kerjasama dan pemahaman siswa terhadap materi yang dibahas.

\section{Tahap Pengamatan \\ Collaborative Skill}

Pengamatan yang diperoleh dari aktivitas siswa dalam melaksanakan model pembelajaran group investigation dengan bantuan magic ball yang menjadi cerminan collaborative skill matematika siswa pada tiap siklus adalah sebagai berikut: 
Tabel 3. Collaborative Skill Matematika Siswa dalam Model Pembelajaran Group Investigation Dengan Bantuan Magic Ball

\begin{tabular}{|c|c|c|}
\hline Indikator Collaborative Skill & Siklus I & Siklus II \\
\hline $\begin{array}{l}\text { Secara bersama-sama memiliki } \\
\text { tanggung jawab dalam pemecahan } \\
\text { masalah }\end{array}$ & $52 \%$ & $76 \%$ \\
\hline $\begin{array}{l}\text { Aktif berkontribusi dalam } \\
\text { mengemukakan pendapat }\end{array}$ & $48 \%$ & $68 \%$ \\
\hline $\begin{array}{l}\text { Mengerahkan kemampuan secara } \\
\text { maksimal }\end{array}$ & $56 \%$ & $74 \%$ \\
\hline $\begin{array}{l}\text { Membina hubungan baik dengan } \\
\text { rekan }\end{array}$ & $66 \%$ & $72 \%$ \\
\hline Menghadapi masalah bersama-sama & $60 \%$ & $80 \%$ \\
\hline $\begin{array}{l}\text { Percaya pada kemampuan anggota } \\
\text { dalam kelompok }\end{array}$ & $50 \%$ & $68 \%$ \\
\hline $\begin{array}{l}\text { Memiliki prosedur kerja kelompok } \\
\text { yang efektif }\end{array}$ & $54 \%$ & $72 \%$ \\
\hline $\begin{array}{l}\text { Mengutamakan } \quad \text { keterampilan } \\
\text { mendengar }\end{array}$ & $70 \%$ & $85 \%$ \\
\hline Mengevaluasi proses kerja & $46 \%$ & $66 \%$ \\
\hline Rata-rata & $55.77 \%$ & $73.44 \%$ \\
\hline Kategori & Tinggi & Sangat Tingg \\
\hline
\end{tabular}

Berdasarkan hasil pengamatan terhadap collaborative skill matematika siswa siklus I siswa memperoleh nilai rata-rata sebesar $55.77 \%$, nilai ini merupakan kategori tinggi. Pada masingmasing indikator berjalan dengan baik namun belum maksimal, pada indikator tanggung jawab bersama dalam pemecahan masalah siswa memiliki persentase $52 \%$ hal ini menggambarkan masih sebagian siswa yang memiliki rasa tanggung jawab dalam memecahkan masalah terlihat dari masih terdapat siswa yang tidak terlibat aktif dalam pemecahan masalah yang disajikan, pada indikator aktif mengemukakan pendapat hanya 3 orang siswa dari 3 kelompok yang mau mengemukakan pendapatnya dalam pembelajaran artinya 3 kelompok lainnya masih belum aktif dalam mengemukakan pendapatnya, pada indikator pengerahan kemampuan belum maksimal terlihat dari antusiasme siswa yang kurang sehingga siswa masih enggan dalam melakukan investigasi terhadap sajian soal dalam magic ball, pada indikator pembinaan hubungan baik dengan rekan cukup baik karena satu sama lain sudah kenal dekat namun belum terjalin kerjasama yang baik, pada indikator menghadapi masalah kurang kompak terlihat dari masing- masing kelompok tidak semua berperan aktif seperti ada kelompok yang hanya ada 1 orang siswa yang mengukur panjang persegi untuk dihitung keliling dan luasnya, dan satu orang lagi mencari magic ball yang berisi jawaban yang tepat sedangkan 4 orang siswa lainnya hanya seolah mengamati aktivitas teman dalam kelompoknya. Pada indikator percaya pada kemampuan anggota masih belum baik karena masing-masing siswa tidak membagi tugas secara merata, maksudnya hanya beberapa siswa yang mau terlibat dan mengabaikan siswa lainnya yang dirasa kurang aktif, pada indikator prosedur kerja juga belum efektif karena tidak dilakukan secara bersama dan proporsional jadi beberapa kegiatan dilakukan oleh 1 orang saja seperti mengambil magic ball dan menjawabnya sendiri sehingga hal ini kurang efektif. Indikator keterampilan mendengar cukup baik namun dalam pelaksanaannya kurang berjalan seperti yang disampaikan oleh guru, pada indikator evaluasi proses kerja tampak tidak ada yang melakukan koreksi ulang terhadap kegiatan yang dilakukan, hanya saja melihat apakah semua sudah dijawab atau belum sehingga ditemukan beberapa kekeliruan dan kekurangan dalam menjawab soal seperti salah pengukuran panjang 
persegi dan perhitungannya.

Berdasarkan hasil siklus I, terdapat beberapa catatan yang menjadi acuan perbaikan siklus II antara lain 1) guru harus menciptakan rasa tanggung jawab setiap siswa untuk memecahkan masalah, 2) setiap kelompok harus mengemukakan pendapatnya minimal 2 siswa dalam kelompoknya, 3) setiap siswa harus berperan aktif dalam pembelajaran dengan cara melakukan peran yang semampunya ia dapat lakukan misal berperan sebagai pengambil bola soal, pencari jawaban, dan menemukan bola berisi jawaban yang dikerjakan sebelumnya, serta mengemukakan pendapat pada guru maupun siswa lain, 4) setiap kelompok harus mengoreksi dan mengevaluasi kerja yang telah dilakukan agar tidak ditemukan kesalahan, siswa dapat berkonsultasi dengan guru mengenai hasil investigasi yang mereka peroleh.

Berdasarkan perbaikan tersebut, maka pada siklus II mengalami peningkatan yang lebih baik dimana collaborative skill matematika siswa mencapai kategori sangat tinggi dengan nilai ratarata sebesar $73.44 \%$. Siswa merasa bertanggung jawab untuk menemukan pemecahan masalah yang disajikan dengan turut aktif dalam kelompoknya, siswa juga aktif memberikan pendapat dengan bertanya pada teman sekelompoknya ataupun memberikan penjelasan pada siswa lain yang tidak mengerti, terlihat bahwa siswa mulai mengerahkan kemampuan sebisa mungkin yang dapat ia lakukan, satu sama lain siswa saling berbagi dan membantu hal ini menujukkan adanya pengembangan kemampuan social seperti menghormati, mematuhi peraturan, penyelesaian tugas, dan tolerasnsi (Tavakoli, 2014). jika ditemukan masalah maka dengan sigap mereka mencari solusi alternatif agar masalah dapat diselesaikan dengan baik, pembagian tugaspun sudah terlihat baik karena tampak tidak ada siswa yang hanya diam melainkan berperan dengan peran yang sudah diorganisasikan, pada indikator prosedur sudah berjalan dengan efektif dan efisien sehingga penyelesaian masalah tampak lebih mudah dan cepat karena masing-masing siswa menjalankan sesuai dengan rencana yang disusun, siswa juga selalu terbuka menerima masukan dari guru agar dapat melakukan kegiatan investigasi dengan baik, pada akhirnya siswapun tidak tergesa-gesa dalam mengambil kesimpulan dengan cara melakukan evaluasi terlebih dahulu apakah perencanaan, proses investigasi, dan hasil sudah menemukan titik temu dan jawaban yang tepat. Peningkatan ini juga merupakan pengaruh media dan model pembelajaran yang tepat karena siswa lebih menyukai belajar sambil bermain dibandingkan diberikan penjelasan (ceramah), terlihat dari penggunaan media seperti magic ball atau bahkan permainan ular tangga (Febriana, 2018).

Peningkatan aktivitas kerjasama antar siswa, daya penalaran, dan kemampuan berpikir ini merupakan cerminan bahwa group investigation mendorong siswa untuk mengumpulkan informasi untuk pemecahan masalah dan mengaktifkan kemampuan berpikir tingkat tinggi (Kronberg dan Griffin, 2000).

\section{Hasil Belajar}

Adapun hasil belajar siswa setelah
diterapkan model pembelajaran group
investigation dengan bantuan magic ball dapat
dilihat pada graif berikut berikut:




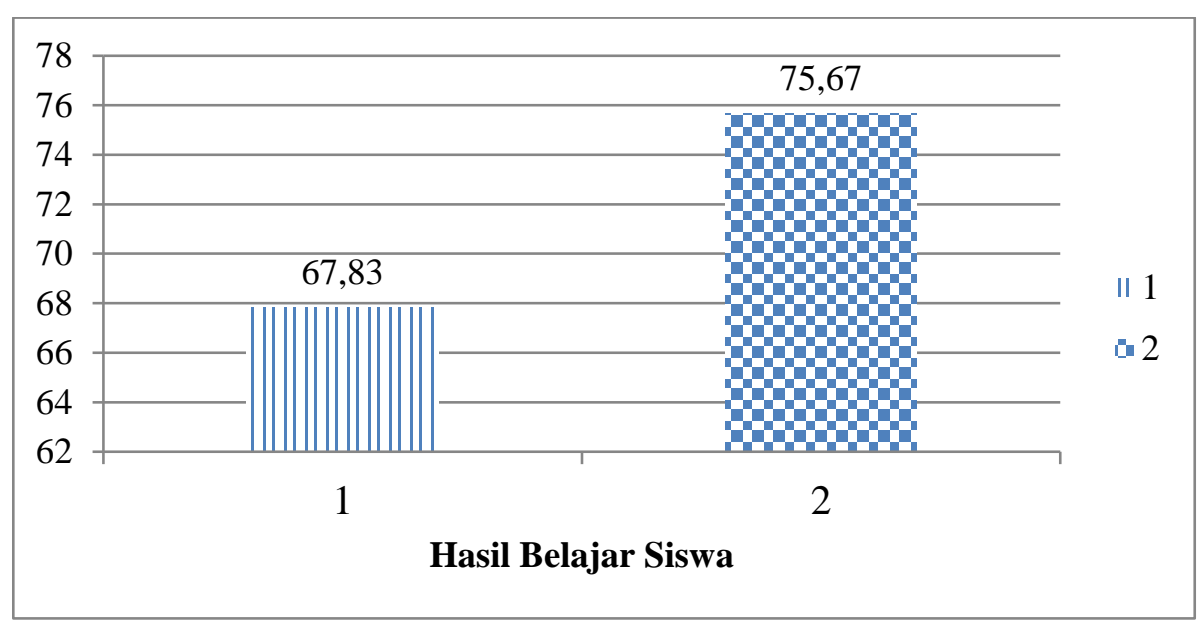

Gambar 1. Rata-rata Hasil Belajar Siswa Siklus I danII

Berdasarkan rata-rata hasil belajar siswa pada gambar 1 tersebut, terlihat bahwa pada siklus I siswa memperoleh 67.83 artinya ini belum mencapai KKM yang ditetapkan, pada siklus II siswa mencapai rata-rata hasil belajar sebesar 75.67 yang sudah mencapai KKM yang ditetapkan. Secara klasikal pada siklus 1 terdapat 16 dari 30 siswa yang mencapai ketuntasan klasikal dengan persentase $53 \%$ artinya belum mencapai ketuntasan yang diharapkan yakni $80 \%$. Pada siklus II mengalami peningkatan ketuntasan secara klasikal yakni sebanya 25 dari 30 siswa atau dengan persentase sebesar $83 \%$ yang telah melampaui ketuntasan klasikal yang ditetapkan. Kemampuan siswa tampak lebih baik dengan pemahaman siswa yang dapat membedakan antara persegi dan persegi panjang, siswa juga mampu menghitung keliling dan luasnya secara tepat, selain itu siswa dapat memberikan contoh persegi dan persegi panjang dalam kehidupan sehari-hari seperti permainan ular tangga merupakan contoh persegi dan papan tulis merupakan contoh persegi panjang. Keberhasilan ini senada dengan Surya (2018) dan Riya (2017) yang mengemukakan bahwa pembelajaran yang dikemas dengan melibatkan kebersamaan dalam belajar dan dibantu

\section{SIMPULAN DAN REKOMENDASI}

Penelitian ini menghasilkan persentase rata-rata collaborative skill matematika siswa pada dengan media berupa magic ball atau kartu domino dapat meningkatkan hasil belajar siswa. Hal ini juga diungkapkan oleh Rini dan Asep (2019) bahwa hasil belajar siswa baik pada aspek kognitif, afektif, dan psikomotorik mengalami peningkatan setelah diterapkan meode group investigation.

\section{Tahap Refleksi}

Berdasarkan hasil penelitian pada siklus I collaborative skill matematika siswa belum mencapai kategori yang diharapkan sehingga perlu adanya perbaikan dengan beberapa catatan yang akan dilakukan pada siklus II, dengan adanya perbaikan tersebut memberikan pengaruh positif terhadap collaborative skill siswa pada siklus II yakni mencapai rata-rata sebesar $73.44 \%$ yang mrupakan kategori sangat tinggi. Hasil belajar siswa pada siklus I belum mencapai KKM dan secara klasikal juga belum sepenuhnya berhasil sehingga perbaikan pada siklus II memberikan pengaruh yang baik dengan pencapaian yang diperoleh siswa yakni hasil belajar siswa pada siklus II memiliki rata-rata sebesar 75.67 dengan persentase ketuntasan klasikal sebesar 83\%. Hal ini menunjukkan bahwa penelitian ini berhasil dan tidak perlu dilanjutkan pada siklus berikutnya.

siklus I dan II masing-masing sebesar 55.77 kategori tinggi dan 73.44 dengan kategori sangat 
tinggi, serta hasil belajar siswa siklus I sebesar 67.83 meningkat pada siklus II menjadi 75.67 dengan persentase klasikal siklus I sebesar 53\% menjadi $83 \%$ pada siklus II. Kesimpulan yang dapat ditarik berdasarkan hasil penelitian adalah bahwa melalui model pembelajaran group investigation berbantuan magic ball dapat meningkatkan collaborative skill matematika dan hasil belajar siswa kelas III SDN 008 Talang

\section{DAFTAR PUSTAKA}

Agustina, R. (2011). Upaya Meningkatkan Minat Belajar Mahasiswa Melalui Model Pembelajaran Group Investigation pada Mata Kuliah Pengetahuan Lingkungan di Program Studi Pendidikan Biologi FKIP Unigha. Sains Riset, 1 (2).

Avisca, K, C, W., Mawardi., Astuti, S. (2018). Upaya Peningkatan Critical Thinking dan Collaborative Skill Matematika Melalui Penerapan Model Group Investigation Berbantuan Magic Ball. Jurnal pendidikan, 3 (2), 97-103.

Elhefni. (2011). Model Pembelajaran Kooperatif Tipe Think Pair Share dan Hasil Belajar di Sekolah. Ta'dib, 16 (2), 303-319.

Febriana, S, G., Mawardi., dan Astuti, S. (2018). Penerapan Model Pembelajaran Team Game Tournament Berbantu Media Ular Tangga untuk Meningkatkan Keterampilan Collaborative Siswa SD. Jurnal Ilmiah Pendidikan dan Pembelajaran, 2 (2), 222228.

Halimah., Mawardi., Wardani, K, W. (2019). Peningkatan Keterampilan Kolaborasi pada Mata Pelajaran Matematika Kelas 4 SDN Gendongan 03 Melalui Penerapan Model Pembelajaran Team Game Tournament (TGT). Journal for Lesson and Learning Studies, 2 (1), 46-52.

Isjoni, H. (2009). Pembelajaran Kooperatif Meningkatkan Kecerdasan Komunikasi Antar Peserta Didik. Yogyakarta: Pustaka Pelajar.

Kristianti, Y., Mawardi, Astuti, S. (2019). Peningkatan Collaborative Skill dan Hasil Belajar Matematika Siswa Kelas 4 Melalui
Perigi.

Rekomendasi yang dapat diajukan adalah agar peneliti selanjutnya dapat membuat modifikasi media yang lebih menarik seperti permainan ular tangga, kartu, maupun alat peraga sederhana yang menarik perhatian dan antusiasme siswa dalam belajar dengan menyenangkan dan bermakna.

Model Team Game Tournament. Phytagoras, 8 (1), 1-10.

Kronberg, J., dan Griffin, M. (2000). Analysis Problem, A Means to Developing Students' Critical Thinking Skills. Journal of College Science Teaching, 24 (5), 348-352.

Puspitasari, N. (2017). Peningkatan Collaboration Skill Siswa Sebagai Kecakapan Abad 21 Melalui Pembelajaran Model Cooperative Learning Tipe Team Accelerated Instruction (TAI) Mata Pelajaran IPA di SD Negeri Kotagede 1. Jurnal Pendidikan Guru Sekolah Dasar, 38 (7), 767-780.

Rini, C, P., dan Suherman, A. (2019). Penerapan Metode Group Investigation (GI) untuk Meningkatkan Hasil Belajar IPA Siswa Kelas VI SD Penerus Bangsa Kota Tangerang. Jurnal Pendidikan Dasar Nusantara, 5 (1), 150-163.

Rosita, I. (2013). Meningkatkan Kerjasama Siswa Melalui Pembelajaran Kooperatif Tipe Think Pair Share. Formatif: Jurnal Ilmiah Pendidikan MIPA, 3 (1), 1-10.

Sadikin., Fahinu., dan Ruslan. (2016). Pengaruh Penerapan Model Pembelajaran Group Investigation dan Self Concept Terhadap Kemampuan Berpikir Kritis Matematik Siswa SMA. Jurnal Pembelajaran Berpikir Matematika, 1 (2), 31-44.

Saleh, H, I., Nurhayati, B., Jumadi, O. (2015). Pengaruh Penggunaan Media Alat Peraga Terhadap Hasil Belajar Siswa pada Materi Sistem Peredaran Darah Kelas VIII SMP Negeri 2 Bulukumba. Jurnal Sainsmat, 4 (1), 7-13. 
Jurnal PAJAR (Pendidikan dan Pengajaran)

Volume 4 Nomor 2 Maret 2020 | ISSN Cetak : 2580 - 8435 | ISSN Online : 2614 - 1337

DOI : http://dx.doi.org/10.33578/pir.v4i2.7976

Suprijono, A. (2009). Cooperative Learning: Teori \& Aplikasi PAIKEM. Pustaka Pelajar.

Tavakoli, Y., dan Soltani, A. (2014). The Effect of Cooperative Learning on Students' Social Skills in the Experimental Science Course. Journal of Education and Practice, 5 (7), 36-44. 